RESEARCH REPORT

\title{
Local economy and sickness absence: prospective cohort study
}

\author{
Marianna Virtanen, Mika Kivimäki, Marko Elovainio, Pekka Virtanen, Jussi Vahtera
}

J Epidemiol Community Health 2005;59:973-978. doi: 10.1136/jech.2005.036236

\begin{abstract}
See end of article for authors' affiliations

....................

Correspondence to: Dr M Virtanen, Finnish Institute of Occupational Health, Department of Psychology,

Topeliuksenkatu $41 \mathrm{aA}$, FIN-00250 Helsinki, Finland; marianna. virtanen@Ht.fi
\end{abstract}

Accepted 31 May 2005

\begin{abstract}
Study objective: To investigate the effect of the local economy, as measured by municipal revenue and local unemployment rate, on sickness absence among the employed.

Design: A prospective cohort study of 60160 public sector employees (46 081 women, 14079 men) with ecological measures of municipal revenue and local unemployment rate 1999-2000 and individual measures of sickness absence at baseline 1999 and at follow up 2000-2001.

Results: Among men and women, constantly poor local economy, as shown by low municipal revenue and high unemployment rate, was related to decreased self certified sickness absence rates. Local unemployment rate was a stronger predictor of self certified sickness absence than municipal revenue and the effect was stronger among men than among women. High unemployment rate predicted increased medically certified sickness absence among women.

Conclusions: Working in areas of poor local economy is associated with increased long term sickness absence but decreased probability to take a short term sick leave. Unemployment rate may have an effect on the threshold to take a sick leave in relation to minor illnesses even when area deprivation poses health risk to its residents. To prevent adverse health effects of presenteeism, working while ill, and to reduce medically certified sickness absence, potential benefits may be attained by improving economic conditions and re-employment in deprived areas.
\end{abstract}

$\mathrm{S}$ ickness absence is generally considered as a measure of health. On the other hand, ill health is not the only context of a sickness absence event. The level of sickness absence is influenced by values and cultures of the communities, expressed as moral evaluations of the coworkers, habitual practices within organisations and local populations, and attitudes in the society at large as expressed in agreements about gate keeping and legislative regulations. For example, people are less likely to be absent from work because of sickness when they are faced with a potential threat of unemployment. ${ }^{1-5}$ A cross sectional study in Sweden showed lower long term sickness absence ( $>30$ days) among men but not among women, in the localities with a high unemployment rate. ${ }^{6}$ In Canada, back pain claim rates, a possible correlate of sickness absence, increased during boom and decreased during recessionary periods. ${ }^{7}$ A British study reported that there was a cross sectional but no longitudinal effect between high local unemployment rate and high sickness absence. ${ }^{8}$ Leigh found in his study that self reported absenteeism decreased when unemployment increased. ${ }^{9}$ In Finland, the national insurance statistics showed that during the recession in the beginning of the 1990s, the total number of sickness allowance periods per year declined by nearly $30 \%{ }^{4}$ Along with the recovery period towards the end of the century, the number of sick leaves begun to increase.

In addition to lack of longitudinal cohort studies, the earlier studies were unable to differentiate between self certified and medically certified sickness absence within the same study design. This is an important aspect because medically certified sickness absence has shown to be strongly related to ill health whereas self certified absences more often may be associated with other contexts than illness. ${ }^{10-12}$ One of the studies was restricted to employees who were heads of households, ${ }^{9}$ and the studies using ecological measure of both unemployment and sickness absence may have been biased because of ecological fallacy. ${ }^{8} 9$ Furthermore, women usually have higher sickness absence rates than men. It has been suggested that the largest sex differences for illnesses for which men and women seek medical care are related to mild morbidity. ${ }^{13}{ }^{14}$ Contextual factors, such as local economy, may therefore have different effects on the sickness absence levels of men and women. This study examined whether local economy, as measured by the commonly used unemployment rate and in addition, by the municipal revenue, is associated with subsequent sickness absence in men and women.

\section{METHODS}

\section{The municipalities}

In Finland, municipalities are the basic unit of local government. They have legislative responsibility to provide health care, social services, basic education, infrastructure, rental apartments as well as cultural, sports, and other leisure activities for their inhabitants. For specialised health care there are public hospitals organised by the municipalities within the specified area (hospital district). In 2001, about $70 \%$ of general practitioner services and $95 \%$ of hospital care were provided by municipalities. ${ }^{15}$ The municipalities mainly fund their services with taxes collected from their inhabitants and local enterprises as well as with the subsidy received from the state. The proportion of governmental subsidy is about $30 \%$ of the municipal revenue and the idea of the subsidy is to even out the income inequality between the communities. However, inequality still exists despite the subsidy. ${ }^{16}$

In early 1990s, Finland's national economy faced a severe recession, and unemployment rate was as high as $17 \%$ in 1993, the worst year of the recession. This meant reduced revenues for the municipalities that had to cut off the personnel and services. Along with the recovery the unemployment rate decreased and the municipal revenue began to grow. However, the growth of the municipal economy did not take place evenly in all parts of the country. ${ }^{16}$ 
Table 1 Characteristics of the participants by municipal revenue and local unemployment rate

\begin{tabular}{|c|c|c|c|c|c|c|c|}
\hline & \multirow[b]{2}{*}{$\begin{array}{l}\text { All participants } \\
(\mathrm{n}=60160)\end{array}$} & \multicolumn{3}{|c|}{ Municipal revenue* } & \multicolumn{3}{|c|}{ Local unemployment rate } \\
\hline & & $\begin{array}{l}2.8-3.1 \\
(n=20078)\end{array}$ & $\begin{array}{l}3.1-3.2 \\
(n=17423)\end{array}$ & $\begin{array}{l}3.2-3.5 \\
(n=22659)\end{array}$ & $\begin{array}{l}>8-13 \\
(n=19323)\end{array}$ & $\begin{array}{l}>13-14 \\
(n=19550)\end{array}$ & $\begin{array}{l}>14-18 \\
(n=21287)\end{array}$ \\
\hline \multicolumn{8}{|l|}{ Sex } \\
\hline Men & $14079(23)$ & $5239(26)$ & $4090(24)$ & $4750(21)$ & $4043(21)$ & $7337(38)$ & $2699(13)$ \\
\hline \multicolumn{6}{|l|}{ Age group } & $12213(63)$ & $18588(87)$ \\
\hline$<26$ & $2254(4)$ & $710(4)$ & $623(4)$ & $921(4)$ & $937(5)$ & $656(3)$ & $661(3)$ \\
\hline $26-30$ & $4215(7)$ & $1316(7)$ & $1245(7)$ & 1654 (7) & $1581(8)$ & 1289 (7) & $1345(6)$ \\
\hline $31-35$ & $6898(12)$ & 2246 (11) & $1911(11)$ & $2741(12)$ & $2218(12)$ & 2257 (12) & $2423(11)$ \\
\hline $36-40$ & $9060(15)$ & 3090 (15) & 2362 (14) & 3608 (16) & $2676(14)$ & $2842(15)$ & 3542 (17) \\
\hline $41-45$ & $10801(18)$ & $3681(18)$ & 3048 (18) & $4072(18)$ & $3213(17)$ & $3499(18)$ & 4089 (19) \\
\hline $46-50$ & $11027(18)$ & $3616(18)$ & $3401(20)$ & $4010(18)$ & 3489 (18) & $3585(18)$ & 3953 (19) \\
\hline $51-55$ & 11025 (18) & 3769 (19) & $3396(20)$ & 3860 (17) & $3530(18)$ & 3792 (19) & 3703 (17) \\
\hline$>55$ & $4880(8)$ & $1650(8)$ & 1437 (8) & $1793(8)$ & $1679(9)$ & $1630(8)$ & 1571 (7) \\
\hline \multicolumn{8}{|l|}{ Employee income $†$} \\
\hline Low & 19854 (33) & 6448 (32) & 6587 (38) & $6819(30)$ & 6579 (34) & $6308(32)$ & 6967 (33) \\
\hline Intermediate & $20491(34)$ & $7135(36)$ & 5727 (33) & 7629 (34) & $6210(32)$ & $6960(36)$ & 7321 (34) \\
\hline High & $19815(33)$ & 6495 (32) & 5109 (29) & $8211(36)$ & $6534(34)$ & $6283(32)$ & 6999 (33) \\
\hline \multicolumn{8}{|l|}{ Employment contract } \\
\hline Permanent & 46142 (77) & $15997(80)$ & $13317(76)$ & $16828(74)$ & $14570(75)$ & $15310(78)$ & $16262(76)$ \\
\hline Temporary & 14018 (23) & $4081(20)$ & $4106(24)$ & $5831(26)$ & $4753(25)$ & $4240(22)$ & $5025(24)$ \\
\hline \multicolumn{8}{|l|}{ Employer } \\
\hline Municipality & 46526 (77) & $13953(70)$ & $17423(100)$ & 15150 (67) & $15778(82)$ & $15186(78)$ & $15562(73)$ \\
\hline $\begin{array}{l}\text { Public hospital } \\
\text { Urbanisation levelł }\end{array}$ & $13634(23)$ & $6125(31)$ & $0(0)$ & 7509 (33) & 3545 (18) & $4364(22)$ & 5725 (27) \\
\hline City & $52771(88)$ & $15808(79)$ & $16957(97)$ & $20006(88)$ & $17668(91)$ & $16793(86)$ & $18310(86)$ \\
\hline Town & 7389 (12) & $4270(21)$ & $466(3)$ & $2653(12)$ & $1655(9)$ & $2757(14)$ & $2977(14)$ \\
\hline
\end{tabular}

${ }^{*} € 1000$ per citizen within the municipality (in public hospitals income within occupying municipalities). +Cut off points $€ 1663$ and $€ 2058$ for low and intermediate income in men, and $€ 1425$ and $€ 1732$ in women. $¥$ City: $>100000$ inhabitants; town: $<100000$ inhabitants.

This study focuses on the entire staff of 10 towns and 15 public hospitals in 25 separate areas of southern, western, and northern parts of Finland. The sample covers almost 20\% of the full time employees working in the Finnish municipal sector. The number of population in these communities ranges between 7100 and 210000 , and the number of staff in participating organisations ranges between 150 and 11410 .

\section{Local economy}

The data on the municipal revenue in 1999 and 2000 were obtained from Statistics Finland (official Finnish government statistics). This measure shows tax revenue plus governmental subsidy expressed as euros per citizen. For the 10 towns, we used municipal revenue. For each of the 15 hospitals we calculated the mean score for revenue of the "owner municipalities" weighted by population size. The mean score was $€ 3197$ per citizen in 1999 and $€ 3429$ per citizen in 2000. Municipal revenue was split into thirds to show low, average, and high rate. A change in revenue between 1999 and 2000 was identified if the municipality shifted from one third to another, as defined in 1999. A shift from low to average, low to high, and average to high was found. The categories of staying low and staying high were also identified but not the category of staying average.

According to the official regulations of the Ministry of Labour there are integrated working and job seeking areas in

Table 2 Association between municipal revenue, local unemployment rate, and sickness absence at baseline

\begin{tabular}{|c|c|c|c|c|c|}
\hline & \multirow[b]{2}{*}{ Numbe } & \multicolumn{2}{|c|}{$\begin{array}{l}\text { Self certified sickness } \\
\text { absence }\end{array}$} & \multicolumn{2}{|c|}{$\begin{array}{l}\text { Medically certified sickness } \\
\text { absence }\end{array}$} \\
\hline & & Spells* & $\operatorname{RR}(95 \% \mathrm{Cl}) \dagger$ & Spells* & $\operatorname{RR}(95 \% \mathrm{Cl}) \dagger$ \\
\hline \multicolumn{6}{|l|}{ Men } \\
\hline \multicolumn{6}{|c|}{ Municipal revenue $(€ 1000)$} \\
\hline High (3.2-3.5) & 4750 & 0.98 & 1.00 & 0.60 & 1.00 \\
\hline Average $(3.1-3.2)$ & 4090 & 0.90 & 0.91 (0.87 to 0.95 ) & 0.56 & $0.84(0.80$ to 0.90$)$ \\
\hline Low $(2.8-3.1)$ & 5239 & 0.97 & $0.97(0.93$ to 1.01$)$ & 0.70 & $1.08(1.03$ to 1.14$)$ \\
\hline \multicolumn{6}{|c|}{ Local unemployment rate (\%) } \\
\hline Low $(>8-13)$ & 4043 & 1.07 & 1.00 & 0.57 & 1.00 \\
\hline Average (>13-14) & 7337 & 0.94 & 0.84 (0.81 to 0.88$)$ & 0.66 & $1.04(0.99$ to 1.10$)$ \\
\hline High $(>14-18)$ & 2699 & 0.81 & 0.75 (0.71 to 0.79 ) & 0.59 & $1.04(0.97$ to 1.11$)$ \\
\hline \multicolumn{6}{|c|}{ Women } \\
\hline \multicolumn{6}{|c|}{ Municipal revenue $(€ 1000)$} \\
\hline High (3.2-3.5) & 17909 & 1.53 & 1.00 & 0.79 & 1.00 \\
\hline Average (3.1-3.2) & 13333 & 1.47 & $0.94(0.92$ to 0.96$)$ & 0.78 & 0.91 (0.89 to 0.94$)$ \\
\hline Low $(2.8-3.1)$ & 14839 & 1.42 & 0.96 (0.94 to 0.98 ) & 0.79 & $1.00(0.97$ to 1.02$)$ \\
\hline \multicolumn{6}{|c|}{ Local unemployment rate (\%) } \\
\hline Low $(>8-13)$ & 15280 & 1.69 & 1.00 & 0.75 & 1.00 \\
\hline Average $(>13-14)$ & 12213 & 1.37 & $0.84(0.82$ to 0.86$)$ & 0.73 & 1.00 (0.97 to 1.03$)$ \\
\hline High (>14-18) & 18588 & 1.38 & $0.83(0.82$ to 0.85$)$ & 0.85 & $1.14(1.11$ to 1.17$)$ \\
\hline
\end{tabular}


Finland. The unemployment rate for these areas is collected by Statistics Finland each year. We obtained information on job seeking areas from the Ministry of Labour showing that the participating organisations were located in 15 separate job seeking areas. In 1999, the mean unemployment rate of these areas was $11.3 \%$ in men, and $11.1 \%$ in women. The corresponding figures for 2000 were $9.7 \%$ and $9.6 \%$. The local unemployment rates were split into thirds to show low, average, and high rate. A change in unemployment rate between 1999 and 2000 was identified if the locality shifted from one third to another, as defined in 1999. Both in men and women a shift from high to average, high to low, and average to low was found. The categories of staying high and staying low were also identified. A category of staying average did not exist in these data.

Finally, we combined the measures of municipal revenue and local unemployment rate into one indicator of local economy. Three categories were defined: (1) both constantly good (high revenue and low unemployment); (2) both improved (revenue increased, unemployment decreased) or one of them was constantly good (revenue constantly high and unemployment decreased or constantly high/unemployment constantly low and revenue increased or constantly low); (3) both constantly poor/one poor, one improving (revenue constantly low and unemployment constantly high /revenue constantly low but unemployment decreased/revenue increased but unemployment constantly high). In group 3 , we collapsed the three categories into one because of a small number of cases in the category of "both constantly poor".

\section{Sickness absence}

Data on sickness absences were collected within the ongoing Finnish public sector cohort study. ${ }^{17}{ }^{18}$ Approval of the ethics committee of the Finnish Institute of Occupational Health was obtained for this study. From the employer's registers we identified 62264 employees who were in the service for more than one month each year during 1999-2001. Of them, $60160(97 \%)$ had complete records on sickness absence, demographic factors, and job contracts and formed the final cohort of the study. The regulations for sick leave compensations are similar for all employees after one month's service.

We obtained self certified sickness absence spells (13 days) and medically certified sickness absence spells (>3 days) for each person in 1999, 2000, and 2001 from the employers' registers. We further differentiated the duration of medically certified absence spells into 4-7 days, 8-21 days, and more than 21 days. In accordance with existing regulations, each sick leave certificate, irrespective of the place of issue, must be forwarded to these registers reporting and listing the beginning and end dates. Maternity leaves and absences due to caring for a sick child are not included as sickness absences. The number of contracted days represented "days at risk", from which the number of days absent from work for reasons other than sickness was subtracted. Outcomes were sickness absence rates at baseline in 1999 and sickness absence rates at follow up (2000-2001).

\section{Other variables}

The individual level baseline characteristics, obtained from the employers' records in 1999, were sex, age in five year categories, occupation, type of employment contract (permanent, temporary), employer (town, public hospital), and urbanisation level of the area in which the organisation was located (city:>100 000 inhabitants; town: <100 000 inhabitants). Average monthly income figures itemised separately for women and men by occupational title were obtained from Statistics Finland.

\section{Statistical analysis}

Annual municipal revenue and unemployment rates (the second variable stratified by sex) were linked to each employee. We calculated the number of self certified and medically certified sickness absence spells divided by the time in employment for each employee. The dispersion of sickness absence spells followed the assumptions for Poisson models. Thus, we determined the rate ratios and their $95 \%$ confidence intervals for sickness absence by Poisson regression analysis. Poisson regression models were calculated by using the SAS GENMOD procedure.

\section{RESULTS}

Table 1 shows the characteristics of the participants by the level of municipal revenue and the local unemployment rate. The proportion of women was greater in organisations with high revenue and high unemployment rate $(p<0.001)$. High employee income level was associated with high level of municipal revenue $(p<0.001)$. The proportion of temporary employees among personnel was higher in organisations with high municipal revenue $(\mathrm{p}<0.001)$. Hospital workers were mainly from areas with high unemployment $(p<0.001)$ and from municipalities with high or low but not average level of revenue $(p<0.001)$. The level of revenue was higher and unemployment rate was lower in cities than in smaller towns $(\mathrm{p}<0.001)$. High unemployment rate was associated with low level of revenue $(r=0.19, \mathrm{p}<0.001$, not shown in the table).

Table 2 presents the associations between municipal revenue and local unemployment rate, and sickness absence at baseline 1999. We found significant interactions between the local economy indicators and sex in the association with sickness absences ( $p$ values $<0.05$ ). The analyses were therefore made separately for men and women. In both sexes, lower municipal revenue was associated with lower level of self certified sickness absence rates when compared with high municipal revenue. In a similar vein, in both sexes, average and high local unemployment rates were associated with lower self certified sickness absences when compared with low unemployment rate.

The association between the municipal revenue and medically certified sickness absence was $J$ shaped in men and $U$ shaped in women (table 2). Average revenue was associated with lower sickness absence than high and low revenue. Local unemployment rate was not associated with medically certified sickness absence in men. In women, high unemployment rate was related to higher medically certified sickness absence rate than low unemployment rate.

Table 3 shows the results of the prospective study design. In men, constantly poor municipal revenue and constantly high local unemployment were related to decreased levels of self certified sickness absence ( $p$ for linear trend $<0.001$ ). Similar, although weaker associations for self certified sickness absence rates were found among women. Among men, the association between local unemployment rate and medically certified sickness absence was inverted J shaped, showing increased sickness absence among those in areas in which the unemployment rate had decreased, but decreased sickness absence among those in areas with a constantly high unemployment rate, when compared with employees in areas with constantly low unemployment rate ( $\mathrm{p}$ for curvilinear trend 0.005). Among women, constantly high local unemployment rate was related to increased medically certified sickness absence ( $\mathrm{p}$ for linear trend $<0.001$ ).

In table 4 we combined the measures of municipal revenue and local unemployment rate to assess whether the combination of the two measures ('local economy'). Among both sexes, increasing exposure to poor local economy was related to decreased self certified sickness absence ( $p$ for 


\begin{tabular}{|c|c|c|c|c|c|}
\hline & \multirow[b]{2}{*}{ Number } & \multicolumn{2}{|c|}{ Self certified sickness absence } & \multicolumn{2}{|c|}{$\begin{array}{l}\text { Medically certified sickness } \\
\text { absence }\end{array}$} \\
\hline & & Spells* & RR $(95 \% \mathrm{Cl}) \dagger$ & Spells* & RR $(95 \% \mathrm{Cl}) \dagger$ \\
\hline \multicolumn{6}{|l|}{ Men } \\
\hline \multicolumn{6}{|l|}{ Municipal revenue } \\
\hline Constantly high & 4750 & 1.03 & 1.00 & 0.63 & 1.00 \\
\hline Increased to average/high & 8625 & 0.96 & $0.94(0.91$ to 0.96$)$ & 0.68 & $0.98(0.95$ to 1.01$)$ \\
\hline Constantly low & 704 & 0.82 & $0.87(0.80$ to 0.95$)$ & 0.62 & $0.99(0.89$ to 1.09$)$ \\
\hline \multicolumn{6}{|l|}{ Local unemployment rate } \\
\hline Constantly low & 4043 & 1.16 & 1.00 & 0.59 & 1.00 \\
\hline Decreased to average/low & 9932 & 0.91 & $0.82(0.80$ to 0.84$)$ & 0.69 & $1.07(1.03$ to 1.11$)$ \\
\hline Constantly high & 104 & 0.33 & $0.39(0.30$ to 0.50$)$ & 0.46 & $0.80(0.65$ to 1.00$)$ \\
\hline \multicolumn{6}{|l|}{ Women } \\
\hline \multicolumn{6}{|l|}{ Municipal revenue } \\
\hline Constantly high & 17909 & 1.56 & 1.00 & 0.86 & 1.00 \\
\hline Increased to average/high & 25590 & 1.55 & $1.00(0.99$ to 1.01$)$ & 0.89 & 1.01 (0.99 to 1.02$)$ \\
\hline Constantly low & 2582 & 1.18 & $0.96(0.92$ to 0.99$)$ & 0.78 & $1.02(0.97$ to 1.07$)$ \\
\hline \multicolumn{6}{|l|}{ Local unemployment rate } \\
\hline Constantly low & 15280 & 1.73 & 1.00 & 0.83 & 1.00 \\
\hline Decreased to average/low & 21258 & 1.43 & $0.92(0.91$ to 0.93$)$ & 0.85 & 1.05 (1.03 to 1.07$)$ \\
\hline Constantly high & 9543 & 1.44 & $0.93(0.91$ to 0.94$)$ & 1.00 & $1.15(1.12$ to 1.17$)$ \\
\hline
\end{tabular}

*Number of sickness absence spells/person-year in 2000-2001. †Adjusted for age, employee income, type of employment contract, employer, urbanisation level, and baseline sickness absence.

linear trend $<0.001)$. The effect was stronger in men than in women. With regard to medically certified sickness absence, the two indicators in combination yielded to very similar results to those presented separately in table 3. Among women, increasing exposure to poor local economy was associated with increased medically certified sickness absence ( $\mathrm{p}$ for linear trend $<0.001$ ).

To further examine whether local economy explained medically certified sickness absence spells of different duration we differentiated medically certified sickness absence spells as follows; 4-7 days, 8-21 days, and more than 21 days. The associations between local economy and medically certified sickness absence spells of different duration were to a great extent similar to those obtained by a global measure of medically certified sickness absence spells. For example in men, poor local economy (as defined in table 4) was related to 0.87 (0.74 to 1.02) risk of 4-7 days' absence compared with good local economy. Corresponding figures for 8-21 days' absence in men were 0.99 (0.82 to 1.20 ) and for $>21$ days' absence 1.16 (0.92 to 1.45$)$. In women, poor local economy was associated with 1.12 ( 1.08 to 1.16) risk of 4-7 days' absence. Corresponding figures for
8-21 days' absence in women were 1.21 ( 1.16 to 1.26$)$, and for $>21$ days' absence 1.12 ( 1.06 to 1.19$)$.

\section{DISCUSSION}

This prospective study of over 60000 public sector employees suggests an association between the local economy, as indicated by the municipal revenue and local unemployment rate, and sickness absence. Among men and women, a relation was found between poor local economy and decreased self certified sickness absence. Local unemployment rate was a stronger predictor of self certified sickness absence than was the municipal revenue, and the effect was stronger among men than among women. With regard to medically certified sickness absence, poor local economy increased sickness absence among women. Among men, high local unemployment rate was related to low medically certified sickness absence rate at follow up.

These results on self certified sickness absence are in line with earlier studies showing a decreasing trend in absence during recessionary periods, an increasing trend during boom. $^{2-9}$ Decreasing long term sickness absence only among men corresponds with the study of Knutsson and Goine ${ }^{6}$

\begin{tabular}{|c|c|c|c|c|c|}
\hline & \multirow[b]{2}{*}{ Number } & \multicolumn{2}{|c|}{$\begin{array}{l}\text { Self certified sickness } \\
\text { absence }\end{array}$} & \multicolumn{2}{|c|}{$\begin{array}{l}\text { Medically certified sickness } \\
\text { absence }\end{array}$} \\
\hline & & $\overline{\text { Spells* }}$ & RR $(95 \% \mathrm{Cl}) \dagger$ & Spells* & RR $(95 \% \mathrm{Cl}) \dagger$ \\
\hline \multicolumn{6}{|l|}{ Men } \\
\hline \multicolumn{6}{|c|}{ Municipal revenue and unemployment rate } \\
\hline Both constantly good & 2142 & 1.23 & 1.00 & 0.61 & 1.00 \\
\hline One constantly good/both improved & 11156 & 0.95 & $0.84(0.81$ to 0.87$)$ & 0.67 & $1.03(0.99$ to 1.08$)$ \\
\hline $\begin{array}{l}\text { Both constantly poor/one poor, one } \\
\text { improved }\end{array}$ & 781 & 0.77 & $0.69(0.63$ to 0.76$)$ & 0.61 & 0.95 (0.85 to 1.06$)$ \\
\hline \multicolumn{6}{|l|}{ Women } \\
\hline \multicolumn{6}{|c|}{ Municipal revenue and unemployment rate } \\
\hline Both constantly good & 8660 & 1.79 & 1.00 & 0.83 & 1.00 \\
\hline One constantly good/both improved & 27345 & 1.51 & $0.94(0.93$ to 0.95$)$ & 0.86 & 1.05 (1.03 to 1.07$)$ \\
\hline $\begin{array}{l}\text { Both constantly poor/one poor, one } \\
\text { improved }\end{array}$ & 10076 & 1.40 & 0.90 (0.89 to 0.92$)$ & 0.96 & $1.12(1.10$ to 1.15$)$ \\
\hline
\end{tabular}

*Number of sickness absence spells/person year in 2000-2001. †Adjusted for age, employee income, type of employment contract, employer, urbanisation level, and baseline sickness absence. 


\section{What this paper adds}

- Constantly high local unemployment rate is associated with increased medically certified sickness absence in women

- Despite this, constantly poor local economy, as shown by high unemployment rate and low municipal revenue, predicts decreased self certified sickness absence in men and women.

- Local economy may have an effect on the threshold to take a sick leave in relation to minor illnesses even when area deprivation poses health risk to its residents.

- Lower sickness absence rates among the employed in high unemployment areas may also be related to the healthy worker effect.

reporting an association between high unemployment rate and low long term sickness absence among men but not among women. In contrast, Taylor and Pocock ${ }^{8}$ found an association between high local unemployment rate and high sickness absence among men, as examined by ecological measures of unemployment and sickness absence. The authors concluded that the result does not necessarily indicate causation but it is probable that confounding by individual socioeconomic factors may have had influence on the association. In our study, we were able to examine sickness absence at an individual level and adjust the models for several potential confounding factors, including employee socioeconomic position.

Earlier findings suggest that medically certified sickness absence is more strongly related to ill health than is self certified sickness absence. ${ }^{10-12}$ We were able to differentiate these outcomes within the same cohort. Our study showed that local economy indeed has a different effect on self certified and medically certified sickness absences; the poorer the local economy, the lower the self certified sickness absence rate. Self certified sickness absence is entirely based on a person's decision and can be viewed as a behaviour in which subjects take into account both their health and the community in which they work and live. ${ }^{19}$ Thus, these results are probably not confounded by differences in the availability of health services between the localities or variation in physicians' practices between the occupational health care units.

Furthermore, we were able to use two indicators of local economy and classify the employees according to the level of exposure during the follow up period. This has not previously been feasible. The results suggest that prolonged exposure to poor local economy is associated with decreased self certified sickness absence rates. Unemployment rate was a particularly strong predictor of self certified sickness absence. When unemployment is high, the employed may avoid absences to minimise their risk of job loss. Between 1991 and 1995 the Finnish municipalities downsized their personnel by $8.5 \%$ on an average. ${ }^{19}$ Towards the end of the century, the number of personnel slightly increased. In line with this, a Finnish study

\section{Policy implications}

To prevent adverse health effects of presenteeism, working while ill, and to reduce medically certified sickness absences, potential benefits may be attained by improving economic conditions and re-employment in deprived areas. of municipal employees showed that downsizing of personnel decreased self certified absences among those who kept their jobs. ${ }^{20}$ In 1999 unemployment rate in Finland was still comparatively high $(9.8 \%$ in men, $10.7 \%$ in women), which shows competition for jobs. Low sickness absence of employees in the areas of high unemployment may also be related to the healthy worker effect in which the healthiest part of the workforce is employed.

The municipal revenue may reflect, in addition to prosperity of the locality as a whole, the employers' economic ability to hire and take care of the personnel. This study showed that high unemployment rate and low level of revenue were interrelated. High unemployment rate inevitably leads to lower tax revenues and higher welfare expenditure. As a consequence, the public sector is obliged to downsize the personnel. Our results showed that the lower the revenue was, the lower was the number of temporary workers in the organisation. Low income municipalities may not have resources to hire temporaries to cover short term sick leaves. When short term absences are not covered, the employees may be more reluctant to take sick leave because of extra burden on the colleagues. However, low sickness absence rates are not exclusively desirable. A recent report from the Whitehall II study showed that the incidence of serious coronary events was twice as high among unhealthy employees who worked while ill as that of the unhealthy employees who took sick leaves. ${ }^{21}$ As absence provides scope for recovery for ill employees, presenteeism, working while ill, is likely to impede recovery and may contribute to existing ill health.

This study showed that constantly high unemployment rate was related to increased medically certified sickness absence rate among women. This study confirms earlier research showing the association between local deprivation and morbidity of the residents. ${ }^{22-24}$ Adverse health effects of unemployment may have an influence on the whole community and families, and in this study, on the spouse of the primary wage earner of the family, who in turn, may be unemployed. ${ }^{25}{ }^{26}$ The factors related to material hardship and social well being may contribute this association. ${ }^{22-26}$ From this viewpoint, not only is the health of those actually unemployed at risk but also their immediate family and the community at large.

Furthermore, as the vast majority of personnel in the municipalities and public hospitals have interface with clients, unemployment and other social disadvantage among the people in the area they are working in may induce extra burden on the personnel. However, increased medically certified sickness absence rates may also be a consequence of area inequalities in the supply of health services. ${ }^{27}$ In the more deprived areas people are forced to queue for, for example, medical operation, for a longer time than in the more wealthier areas.

In women, low level of self certified sickness absence and high level of medically certified sickness absence in the high unemployment areas may also be a cost of presenteeism. In men, poor local economy seemed to decrease both self certified and medically certified sickness absence. This is in line with the study of Leigh ${ }^{9}$ in which absenteeism among the employed men decreased when local unemployment increased. The heads of households who usually are men, may keep their absence level low because of a fear of unemployment. On the other hand, in Finland women have a great economic responsibility in the family and a high level of participation in the labour market. An alternative explanation for the sex differences found in this study may be related to municipal personnel reductions during the 1990s. Reductions were more common in the areas with poor local economy than in the wealthy areas and among women than among men. Consequently, the self certified sickness absence 
of the remaining personnel decreased while the medically certified sickness absence increased..$^{20}{ }^{28}$ Our finding on the association between poor local economy and medically certified sickness absence in women may reflect the consequences of personnel reductions in their workplaces. Organisational downsizing has been suggested to entail health risk because of heightened job demands and job insecurity and decreased job control.

A methodological advantage of this study was the high quality of the sickness absence records that permitted reliable measurement of sickness absences, and the assured quality of Statistics Finland as a recorder of unemployment and municipal revenue. We avoided common method variance by using three independent register based data sources. Although the possibility of confounding by an unknown factor can never be fully excluded, we were able to adjust several confounding factors. Our sickness absence measure obtained from the employers' records is probably better in terms of coverage, accuracy, and consistency over time than that attainable by self reports. ${ }^{29}$

\section{CONCLUSIONS}

Constantly poor local economy is associated with increased medically certified sickness absence in women, which may show the adverse health effects unemployment, personnel downsizing, and other social disadvantage has on communities. Despite this, constantly poor local economy predicts decreased self certified sickness absence in both sexes. This may relate to sickness presenteeism, working while ill, or healthy worker effect. Unemployment rate may have an effect on the threshold to take a sick leave in relation to minor illnesses even when area deprivation poses health risk to its residents. To prevent adverse health effects of presenteeism and to reduce medically certified sickness absence potential benefits may be attained by improving economic conditions and re-employment in deprived areas.

\section{ACKNOWLEDGEMENTS}

The authors thank Dr Jane E Ferrie for providing insightful advice and comment.

\section{CONTRIBUTORS}

$\mathrm{MV}$, guarantor for the paper, with MK, JV, ME, and PV designed the hypothesis, analysed the data, and wrote the paper.

\section{Authors' affiliations}

M Virtanen, M Kivimäki, J Vahtera, Finnish Institute of Occupational Health, Helsinki, Finland

M Kivimäki, University of Helsinki, Department of Psychology, Helsinki, Finland

M Elovainio, National Research and Development Centre for Welfare and Health, Helsinki, Finland

P Virtanen, School of Public Health, University of Tampere, and

Pirkanmaa Hospital District, Tampere, Finland

Funding: MK, MV, and JV were supported by the Academy of Finland (projects 104891, 105195 and 77560) and the Finnish Environment Fund.

Conflict of interest: none declared.

Ethics approval: approval of the ethics committee of the Finnish Institute of Occupational Health was obtained for this study.

\section{REFERENCES}

1 Kristensen T. Sickness absence and work strain among Danish slaughterhouse workers: an analysis of absence from work as coping behaviour. Soc Sci Med 1991;32:15-27.

2 Colledge M. Economic cycles and health. Towards a sociological understanding of the impact of the recession on health and illness. Soc Sci Med 1982; 16:1919-27.

3 Beale N, Nethercott S. Certificated sickness absence in industrial employees threatened with redundancy. BMJ 1988;296:1508-10.

4 Salminen JK. Talouslama ja sairauslomat. [Economic depression and sick leaves, in Finnish with English abstract]. Suomen Lääkärilehti 2003:58:21-4

5 Virtanen P. 'An epidemic of good health' at the workplace. Sociol Health Illness 1994; 16:394-401.

6 Knutsson A, Goine H. Occupation and unemployment rates as predictors of long term sickness absence in two Swedish countries. Soc Sci Med 1998;47:25-31.

7 Brooker A, Frank JW, Tarasuk VS. Back pain claim rates and the business cycle. Soc Sci Med 1997;45:429-39.

8 Taylor PJ, Pocock SJ. Post-war trends in sickness absence and unemployment in Great Britain. Lancet 1969;22:1120-3.

9 Leigh JP. The effects of unemployment and the business cycle on absenteeism. Journal of Economics and Business 1985;37:159-70.

10 Vahtera J, Pentti J, Kivimäki M. Sickness absence as a predictor of mortality among male and female employees. J Epidemiol Community Health 2004;58:321-6.

11 Marmot MG, Feeney A, Shipley M, et al. Sickness absence as a measure of health status and functioning: from the UK Whitehall II study. J Epidemiol Community Health 1995;49:124-30.

12 Kivimäki $M$, Head J, Ferrie JE, et al. Sickness absence as a global measure of health: evidence from mortality in the Whitehall II prospective cohort study. BMJ 2003:327:364.

13 Hibbard JH, Pope CR. Another look at sex differences in the use of medical care: illness orientation and the types of morbidities for which services are used. Women Health 1986;11:21-37.

14 Feeney A, North F, Head J, et al. Socioeconomic and sex differences in reason for sickness absence from the Whitehall II study. Occup Environ Med 1998;55:91-8.

15 Stakes [National Research and Development centre for welfare and health]. Statistical yearbook on social welfare and health care. Social Security 2002;4:148-9.

16 Statistics Finland. http://www.kunnat.net (accessed 7 Feb 2005).

17 Vahtera J, Poikolainen K, Kivimäki M, et al. Alcohol intake and sickness absence: a curvilinear relation. Am J Epidemiol 2002;156:969-76.

18 Kivimäki $M$, Virtanen $M$, Vartia $M$, et al. Workplace bullying and the risk of cardiovascular disease and depression. Occup Environ Med 2003;60:779-83.

19 Virtanen P, Vahtera J, Nakari R, et al. Economy and job contract as contexts of sickness absence practices: revisiting locality and habitus. Soc Sci Med 2004:58:1219-29.

20 Vahtera J, Kivimäki $M$, Pentti J. Effect of organisational downsizing on health of employees. Lancet 1997;350:1 124-8.

21 Kivimäki M, Head J, Ferrie JE, et al. Working while ill as a risk factor for serious coronary events: The Whitehall II study. Am J Public Health 2005;95:98-102

22 Bosma H, van de Mheen D, Borsboom GJJ, et al. Neighborhood socioeconomic status and all-cause mortality. Am J Epidemiol $2001 ; 153: 363-71$

23 van Lenthe, Borrell, Costa, et al. Neighbourhood unemployment and all cause mortality: a comparison of six countries. J Epidemiol Community Health 2005;59:231-7.

24 Sloggett A, Joshi $\mathrm{H}$. Higher mortality in deprived areas: community or personal disadvantage? BMJ 1994;309:1470-4.

25 Bartley M. Unemployment and health: understanding the relationship. J Epidemiol Community Health 1994;48:333-7.

26 Kivimäki $M$, Vahtera J, Elovainio $M$, et al. Death or illness of a family member, violence, interpersonal conflict, and financial difficulties as predictors of sickness absence: longitudinal cohort study on psychological and behavioral links. Psychosom Med 2002;64:817-25.

27 Heikkilä M, Roos M, eds. Sosiaali- ja terveydenhuollon palvelukatsaus 2005, (in Finnish). Helsinki: Sosiaali- ja terveysalan tutkimus- ja kehittämiskeskus, 2004

28 Vahtera J, Kivimäki M, Pentti J, et al. Organisational downsizing, sickness absence, and mortality: 10-town prospective cohort study. BMJ 2004;328:555.

29 van Poppel MN, de Vet HC, Koes BW, et al. Measuring sick leave: a comparison of self-reported data on sick leave and data on company records. Occup Med (Lond) 2002;52:485-90. 